
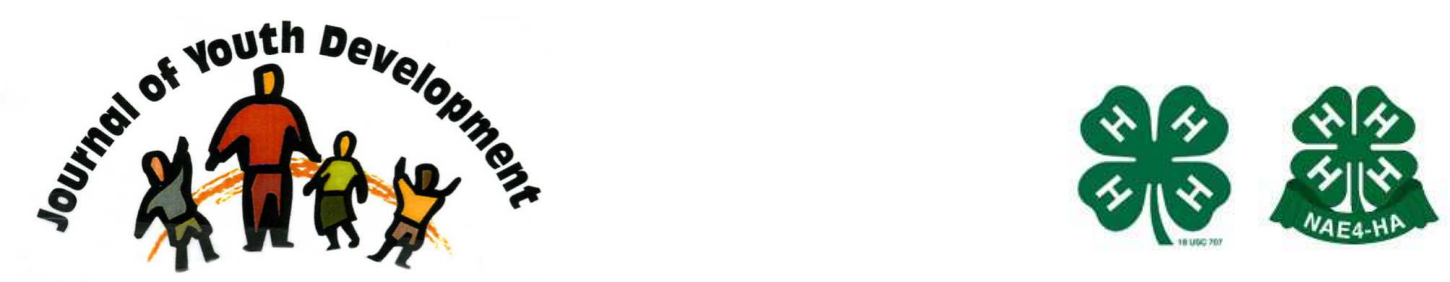

Bridging Research \& Practice

\title{
Take an Adventure Bite
}

College of Agricultural, Human \& Natural Resource Sciences

Washington State University, Pierce County Extension 4-H

Pullman, WA

bbrandt@wsu.edu

\section{Christina Murray}

College of Agricultural, Human \& Natural Resource Sciences

Washington State University, Pierce County Extension 4-H

Pullman, WA

murraychristin@wsu.edu 


\title{
JOURNAL OF YOUTH DEVELOPMENT \\ bridging research and practice

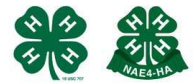

Volume 8, Number 2, Summer 2013

Article 130802PA004

\section{Take an Adventure Bite}

\author{
Brian Brandt and Christina Murray \\ Washington State University, Pierce County Extension 4-H
}

\begin{abstract}
The Adventure Bites - Cooking with Kids program enhanced nutrition curriculum by including a Life Skill development focus and a family night - to improve youth nutrition behaviors. The data was collected using the WSU 4-H Life Skills pre-post youth evaluations, staff surveys, a parent retrospective pre-post survey, and comparison data from non-program sites. The results support adding Life Skills and family night events into youth nutrition curricula. There are opportunities to improve evaluation and do further testing, to determine what the individual impact of Life Skill development and/or individual impact of having family nights had on changes in youth behaviors regarding nutrition.
\end{abstract}

\section{Introduction}

The Surgeon General's Vision for a Healthy and Fit Nation, 2010, cites the growing evidence that the nation is facing a health crisis and nutrition education for youth is one critical part of the solution. Obesity is now the second leading cause of preventable death in Pierce County, resulting in 649 deaths and the potential loss of 7,803 years of life each year (Tacoma - Pierce County Health Board resolution, 2005). Various studies show obesity and poverty to be linked. (Chamber, Duarte, \& Yang, 2009; Drewnowshi, \& Specter, 2004).

Nutrition education shows success when education occurs not only in schools, but other areas in the young person's life as well (Contento, 2007). One high poverty area is the Franklin Pierce School District, in which $61 \%$ of students qualify for free and reduced lunches (OSPI, 2010). To address the issue of obesity in the district, the YMCA of Pierce and Kitsap County's afterschool childcare program piloted the WSU Adventure Bites - Cooking with Kids Program. Its purpose was to measure the impact that adding Life Skills, experiential education, and a family night would have on the behaviors of the youth and parents. The additional Life Skill focused nutrition lessons taught by experiential education methods and a family night showed promising gains in the youth engagement in healthy eating behaviors in the program and at home. 


\section{Theory and Research}

Adventure Bites - Cooking with Kids was designed considering nutrition research, social emotional learning (Life Skills), Social Cognitive Theory, ecological model and experiential education methods. Curricula were selected that increased culinary skills. Youth who have more "culinary confidence," have behaviors supporting better nutrition (Condrasky \& Hegler, 2010). Contento (2007) noted that well-designed and effectively implemented nutrition education can motivate those participating to change dietary behaviors and provide them with the knowledge and skills to make healthy food choices in the context of their lifestyles and economic resources.

Research shows that the combination of new knowledge and social emotional skills, or a targeted Life Skill approach, increases the learning of content better than if the content was taught alone (Catalano, Berglund, Ryan, 2004). Social Cognitive Theory states that more control over the environment leads to greater changes in behavior (Bandura, 1986, 2004). When youth gain confidence and skills, they are improving their sense of control. Youth with more self confidence and control follow through on newly learned behaviors (McLeroy, Bibeau, Steckler, \& Glanz, 1988).

The Ecological Model identifies that parents have great influence over youth behaviors. Traditionally, parents have control over nutritional choices and don't always display good decision making (Gibson, Wardle, \& Watts, 1998). Parents can be a barrier to youth using new nutrition skills and positive nutrition choices (McLeroy, Bibeau, Steckler, \& Glanz, 1988). Programs that positively address parental influence result in greater behavior changes in youth. (Fitzgerald, N. \& Spaccarotella, K. 2009.)

Studies indicate that traditional nutrition education in a lecture and demonstration format doesn't change behavior as much as multifaceted and intentional approaches (Contento, 2007). Teaching techniques that engage the learner, are learner centered, and integrate content are better than teaching these separately (Catalano, Berglund, \& Ryan, 2004). Experiential education programs utilize focused reflection to engage the learner while teaching content.

\section{Program Objectives}

Through partnerships with Schools Out WA, Franklin Pierce School District and the YMCA of Pierce and Kitsap Counties, WSU piloted a program to change poor nutrition behaviors in youth. This was done through training YMCA afterschool providers in Positive Youth Development elements and how to deliver nutrition lessons to youth. The concepts taught to staff include Targeted Life Skills, Ecological Model, Experiential Education Methods, and Social Cognitive Theory.

The program also included objectives for youth to:

- increase gains in nutrition knowledge

- improve the Life Skills decision making, communication, and healthy life style choices to change youth behaviors and give youth skills to influence parents nutrition choices

- increase healthy eating habits at site and home

- positively influence purchases and practices of parents 


\section{Program Description}

The Adventure Bites pilot program investigated the impact of the additional funding, programming and a summative activity on program success, when compared to those without similar resources.

Adventure Bites - Cooking with Kids began with a "train-the-trainer" experiential training workshop that encouraged active participation. Participants were instructed on how to present nutrition activities from the 4-H/Army Youth Development's Up for the Challenge and WSU Pierce County SNAP program curricula, the importance of the Food Pyramid (now My Plate), and ways to keep students on task during a food preparation lesson. YMCA staff added experiential education techniques and targeted Life Skills to the nutrition curricula. After training, initiates taught school age youth the knowledge and skills required to make healthy food choices through hands-on cooking activities.

\section{Example of Lesson Plan}

\begin{tabular}{|c|c|}
\hline $\begin{array}{l}\text { Lesson or Project } \\
\text { Description (DO): } \\
\text { Please note any changes or } \\
\text { adaptations made to the lesson }\end{array}$ & $\begin{array}{l}\text { Discovering the food pyramid. Pages } 26-27 \text { Up for the Challenge. } \\
\text { http://teamnutrition.usda.gov/resources/mpk1_lesson } 1 \text {.pdf } \\
\text { 1. Go over pyramid. Page } 26-27 \text {. Make sure to explain that the less variety in your meals } \\
\text { means less nutrients and energy. } \\
\text { 2. Color in pyramid option. Color paper plates showing faces with energy and little } \\
\text { energy. } \\
\text { 3. Play game everybody is it. Little energy means knees together. }\end{array}$ \\
\hline Life Skills to be Gained: & Healthy Lifestyle Choices \\
\hline $\begin{array}{l}\text { FRAME lesson/content and life skill. } \\
\text { What will you say? and/or What } \\
\text { ACTIVITY will you plan? }\end{array}$ & $\begin{array}{l}\text { Today we will learn more about the food pyramid and play a game based on what we } \\
\text { learn about the food pyramid. }\end{array}$ \\
\hline Question (s) for SHARE (What): & What was interesting about the pyramid? How does this relate to the energy you have? \\
\hline $\begin{array}{l}\text { Question (s) for PROCESS (So } \\
\text { What): }\end{array}$ & $\begin{array}{l}\text { What did you learn about the pyramid? What did you learn about foods impact on your } \\
\text { energy level? }\end{array}$ \\
\hline $\begin{array}{l}\text { Question (s) for GENERALIZE (So } \\
\text { What): }\end{array}$ & Does this relate to anything outside of this class? \\
\hline $\begin{array}{l}\text { Question (s) for APPLY } \\
\text { (Now What): }\end{array}$ & What can you do tonight or tomorrow so you have more energy? What will you do? \\
\hline $\begin{array}{l}\text { ACTIVITY to facilitate reflection ques } \\
\text { Material: One paper plate for each pa } \\
\text { Description: We will draw a face of ho } \\
\text { example plate is good to show a poor } \\
\text { with youth after a good breakfast. If th } \\
\text { ACTIVITY ideas for framing and refle } \\
\text { Game: Low energy high energy tag. } \\
\text { game you have to walk toe to toe. If y } \\
\text { regular walking. When tagged sit dow } \\
\text { be. } \\
\text { What happened with that game? } \\
\text { So What did you learn about how you }\end{array}$ & $\begin{array}{l}\text { ons (optional) } \\
\text { ticipant. Crayons } \\
\text { we are during the day with one food group and the other side with } 4 \text { or more groups. An } \\
\text { oreakfast picture of YMCA staff that have low energy. The other side show staff working } \\
\text { ey want they can just show their face on low energy and high energy. } \\
\text { tion: } \\
\text { ave your plates and drop to the ground. If you are a before scene than when we start the } \\
\text { have an after scene you can walk normally. No running in this game. Only toe to toe or } \\
\text { Practice knee walking first. Play game multiple times. Last version they pick which to }\end{array}$ \\
\hline
\end{tabular}

Note: Food Pyramid has been changed to My Plate

Training was provided for six $(\mathrm{N}=6)$ YMCA sites and included eight hours of training covering experiential education theory, targeted Life Skills approach, nutrition lessons, and Building Successful Learning Communities. 
Sites varied in their access to resources. One site, Elmhurst Elementary, was unique in that its programming level was dictated by a grant. Elmhurst's grant provided financial support for food, required six hours of life skill programming, and a mandated family event. Free from the requirements of the grant, the YMCA dictated programming at a lesser level at the remaining three sites. Those three sites operated with site-specific resources and logistical challenges.

Programming was delivered to students for five months between February 2010 and June 2010. Site staff determined lessons and times based on their differing schedules and needs. The Elmhurst program concluded with a family night, at which youth prepared and presented healthy foods to their families. WSU staff administered all pre/post youth Life Skills tests. YMCA staff administered pre/post youth knowledge tests.

\section{Evidence of Program Success}

The WSU Life Skills evaluation is a valid and reliable tool for youth (Bailey, Bensen, Deen, \& Loeser 2004). It is a pre and post evaluation that was used to assess attitude changes, nutrition knowledge and Life Skill improvement. However, evaluations from young children produce errors and it is recommended to add other evaluation techniques. The designers of the WSU Life Skill evaluation survey have warned that the survey has limitations due to the age of the youth surveyed (Bailey, Bensen, Deen, \& Loeser, 2004).

Evaluating young children can create incorrect data from which to draw conclusions. This can be countered by using multiple evaluation techniques to compare (Flannery, 1990; Sengstock \& Hwalek, 1999; Stone \& Lemanek, 1990). As part of this project staff and parents were also evaluated. The youth, staff, and parents evaluations used similar questions in order to compare results. The three YMCA sites results have been combined as one, serving as a comparison or control group.

Youth and staff at all sites completed the same evaluations. Only parents at the Elmhurst site completed parent evaluations. The Elmhurst site was the only site with supplemental funding, and as such, the only site to complete the projects suggested minimum six hours of instruction, three evaluations, and family event. Three $(n=3)$ other YMCA sites participated. However, those sites did not complete the full six hours of instruction, only completed the staff and youth evaluations, and did not host a family event. They did complete the YMCA's requirements for staff nutrition programming.

The YMCA staff completed a single short retrospective evaluation that observed youth behavior and comments. There were four questions about instruction and nine observation questions. Parents of Elmhurst youth completed a single shot retrospective pre post test survey with six questions using a scale of one to four and three yes/no questions. Staff and parent surveys were similar to the youth survey, but not tested for reliability or validity.

\section{YMCA Elmhurst Site results}

The Elmhurst site had ten youth with a grade breakdown of two in $2^{\text {nd }}$, three in $3^{\text {rd }}$, three in $4^{\text {th }}$, and two in $5^{\text {th }}$ grade. Approximately one hour of lessons occurred each week for five months with youth hosting a family celebration at the end of the year. The Life Skills survey $(n=5)$ a $50 \%$ response rate, showed a $7.6 \%$ increase in the Life Skills of communication and healthy lifestyle choices and an overall increase of 3\% in all Life Skills. Skewing this was the 7.6\% decrease in the Life Skill of decision making. This exposes the concerns of surveying young children with the WSU Life Skills survey as a decrease is highly unlikely. 
The staff evaluation reported $75 \%$ of the youth in the program were open to trying new foods, commenting on helping cooking at home, involved in more physical activity, and eating more fruits and vegetables. At least $50 \%$ of the youth in the program learned something new about cooking, wanted to learn more about healthy eating, and thought about their choices before making decisions. Close to $25 \%$ of the youth listen better when someone is talking. This item showed the least observed improvement.

The parent survey, parents $(n=6)$ a $100 \%$ response rate, all reported they observed youth behavior increases of:

- $69 \%$ in youth asking me to buy a fruit or vegetable that I usually don't buy

- $50 \%$ in helping me cook and prepare meals

- $46 \%$ in youth thinking about their choices before making a decision

- $31 \%$ in asking for help when they do not understand something

- $30 \%$ in listening when someone is talking with them

- $28 \%$ in more willing to taste new foods or foods that he or she usually doesn't eat

Additional yes/no questions:

- $100 \%$ Yes. We now buy healthier snacks for my child to eat

- $100 \%$ Yes. We read nutrition labels when choosing food more often

- $100 \%$ Yes. We eat more meals together as a family

\section{Combined from comparison YMCA sites}

Results from other YMCA sites taking the training $(n=3)$ a response rate of $60 \%$ were combined due to the reported similarities of lack of financial resources, less than the minimum six hours and the lack of a family event. These sites used only the youth and staff evaluations. The youth $(\mathrm{N}=62)$ had $(\mathrm{n}=18)$ complete surveys for a $29 \%$ response rate. Healthy Lifestyle choices showing a gain of $5 \%$, decision making a decrease of $7 \%$, and communication decreased $4 \%$. The average was a 3\% loss of Life Skills. Again this shows issues around youth surveying as decreases are highly unlikely.

Staff observations reported $58 \%$ of the youth were better at listening; $50 \%$ of the time youth ate more vegetables and fruits and they helped cook at home; $41 \%$ of youth were observed to report eating healthier snacks at home and gained knowledge of healthy eating; $33 \%$ of youth were observed to report more physical activity and thinking about their choices before making a decision; and $25 \%$ of youth were observed to try new foods and want to learn more. Being a better listener was the only category scoring higher than Elmhurst. Staff observed an average healthy behavior change in $40 \%$ of youth. 


\section{Table 1}

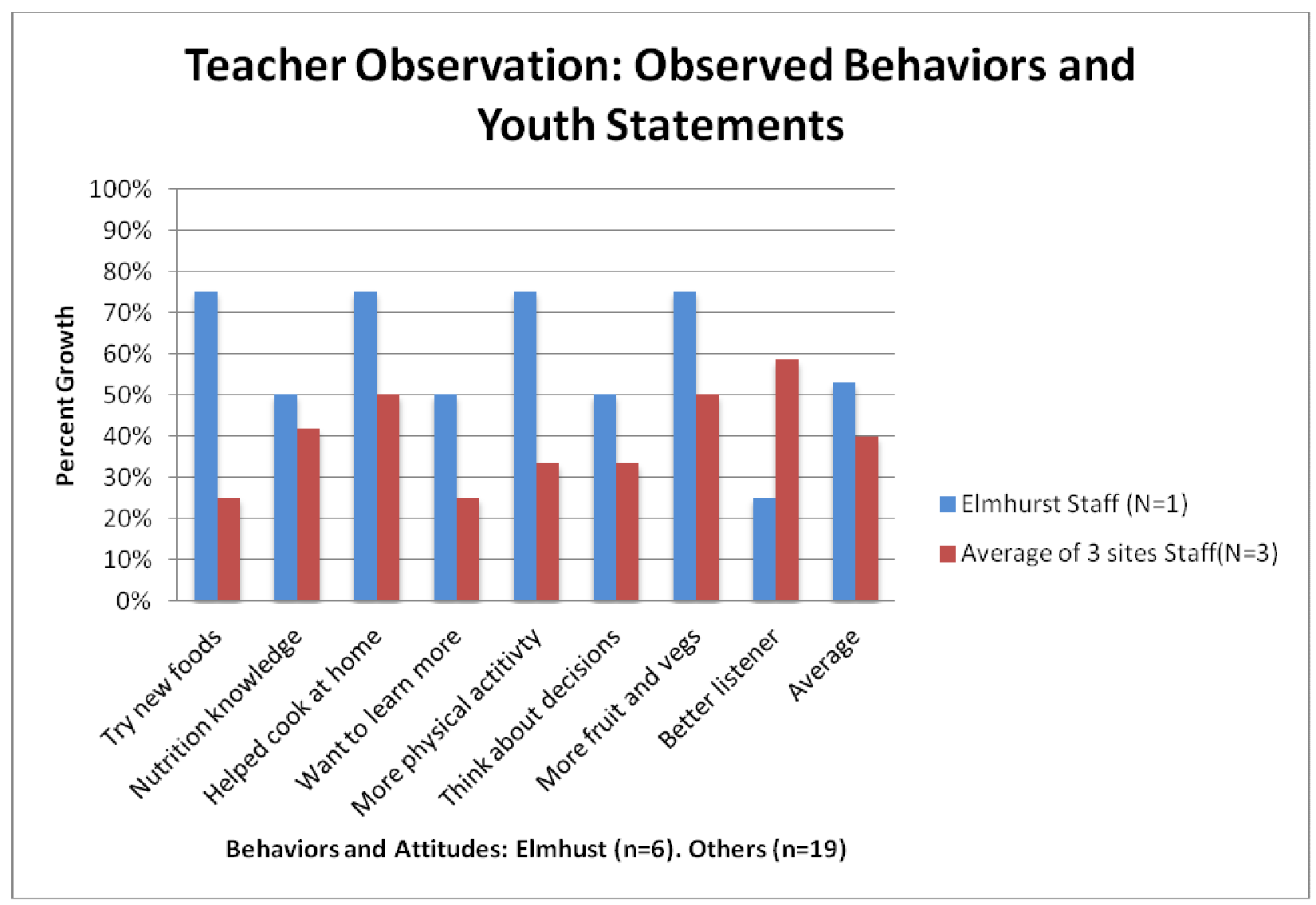

\section{Discussion}

The average of all Life Skill improvement reported by youth for Elmhurst was $6 \%$ greater then the other sites. This 6\% difference shows Elmhurst performing higher in changes in youth's attitude and knowledge around their Life Skills because of greater focus on experiential education discussions.

However, there are shortcomings with this data set. First, the data lacks strong consistency among increases and decreased between Elmhurst and the other sites. A second issue is the unlikely decrease in Life Skills that both sites reported. The third issue was noticed by the evaluators. The timing of surveys disrupted the normal daily sequence and interrupted outside time. Also, many youth opted out and some rushed through the survey. Utilizing this set of data alone doesn't support a strong statement that the program was successful.

The staff observations showed more consistency between Elmhurst and the other sites. However, Elmhurst scored higher with gains in nutritional knowledge, such as, trying new foods, cooking, interest in learning more, playing outside, and eating more fruits and vegetables. Life Skills also showed higher gains. Unfortunately, there are many variables around staffing changes, which were not part of the original design, which could impact the results. Prior staff training, attendance, instructor experience teaching Life Skills, amount of time spent on lessons, time span of observations, and bias all are areas that could affect the results. 
The Elmhurst parent survey is important to consider, as it is outside observations of parents with less investment in reported outcomes than those of the youth or staff. The six Elmhurst parents, a response rate of $100 \%$, reported observing a $43 \%$ average increase in healthy youth behaviors. Life Skills were observed to improve $38 \% .100 \%$ of the parents responded that they now buy healthier snacks, read labels more often, and eat more meals together as a family. The parent survey carries more weight because it is observed behavior changes of youth and the impact it had on the parents' behaviors. Unfortunately, there were no parent surveys from the other groups to compare to Elmhurst.

\section{Conclusions and Implications}

The main question is: would additional nutrition lessons taught with experiential education, financial support, and a family night show promising gains in the youth's engagement in healthy eating behaviors in the program and at home? There is no question that financial support increases the ability to add nutrition lessons in after school programs. Outside of the financial issue, the data shows higher gains in Life Skills and knowledge using the Healthy Bites approach. Youth and staff reported higher behavior and attitude changes in the Elmhurst program compared to the other sites. Unfortunately, only data from the youth and staff evaluations can be used to support this comparison to the other sites. The comparison data supports the assertion that Adventure Bites creates greater changes in youth attitudes, knowledge and behaviors over the other sites programming.

Outside of the youth and staff data, the Elmhurst parents' evaluations are supportive of the program's success. The average improvement for all questions was a $43 \%$ increase in healthy behaviors, compared to those before the program. All parents answered yes to changes in the youth and the behaviors of eating healthier, reading labels together, and eating meals together as a family. This data shows success in the program's changing behaviors in the home environment.

While Adventure Bites was successful with this small group, the data is too limited to allow broad conclusions. Future work with larger numbers of groups participating and randomized control groups would allow for broader statements. Testing each aspect of the curriculum (e.g. Life Skill development, experiential teaching methods, and the family night) separately versus a control group would allow for more specific analysis. This could help determine which aspect of Adventure Bites has the greatest impact on changes in behavior. Adventure Bites'addition of Life Skills, experientially taught lessons, and a family night proved to change the youth healthy eating behaviors at home. This supports youth professionals' altering current nutrition lessons to include Life Skills, teaching experientially, and securing additional funds for a family night event.

\section{References}

Bandura, A. (1986). Social foundations of thought and action: A social cognitive theory. Englewood Cliffs: Prentice-Hall.

Bandura, A. (April 2004 ). Health Promotion by Social Cognitive Means. Health Education

Behavior. 31: 143-164. 
Bailey, S.J., Bensen, R.L., Deen, M.Y, \& Loeser, D.M. (2004). Measuring Impacts with Young Audiences: Adapting a Life-Skills Instrument for Use with Third- to Fifth-Grade Youth.

Catalano, R.F., Berglund, M.L., \& Ryan, J.A.M. (2004). Positive youth development in the United States: Research findings on evaluations of positive youth development programs. Annals of the American.

Chamber, E.C., Duarte, C.S., \& Yang, F.M. (2009). Household Instability, Area Poverty, and Obesity in Urban Mothers and Their Children. Journal of Health Care for the Poor and Underserved. Volume 20, Number 1, February 2009. E-ISSN: 1548-6869 Print ISSN: 1049-2089.

Condrasky, M.D., \& Hegler, M. (2010). How Culinary Nutrition Can Save the Health of a Nation. Journal of Extension,[On-line] 48 (2) Article 2COM1. On-line:

http://www.joe.org/joe/2010april/comm1.php

Contento, I., 2007. Nutrition Education: Linking Theory, Research and Practice. Sudbury, MA: Jones and Bartlett, Publishers.

Drewnowshi, A., \& Specter, SE. (2004). Poverty and obesity: the role of energy density and energy costs American Journal of Clinical Nutrition, 79:6-16.

Fitzgerald, N., \& Spaccarotella, K. (2009). Barriers to a Healthy Lifestyle: From Individuals to Public Policy-An Ecological Perspective. Journal of Extension, [On-line] 47 (1) Article 1FEA3. Online: http://www.joe.org/joe/2009february/a3.php

Flannery, R.C. (1990). Methodological and psychometric considerations in child reports. In A.M. LaGreca (Ed.), Through the eyes of the child: Obtaining self-reports from children and adolescents (pp. 57-82). Boston: Allyn \& Bacon.

Gibson, E.L., Wardle, J., \& Watts, J. (1998). Fruit and vegetable consumption, nutritional knowledge and beliefs in mothers and children. Appetite, 31(2), 205-228.

McLeroy, K.R., Bibeau, D., Steckler, A., \& Glanz, K. (1988). An ecological perspective on health promotion programs. Health Education Quarterly, 15(4), 351-377.

School Report Card. (2010). Office of Superintendent of Public Instruction. Retrieved December 20, 2010, from

http://www.k12.wa.us/Communications/PressReleases2010/StateTestResults.aspx.

Sengstock. M., \& Hwalek. M. (1999). Issues to Be Considered in Evaluating Programs for Children." NEW DESIGNS for Youth Development. 15 (2).

Stone, W.L., \& Lemanek, K.L. (1990). Developmental issues in children's self-reports. In A.M. LaGreca (Ed.), Through the eyes of the child: Obtaining self-reports from children and adolescents (pp. 18-56). Boston: Allyn \& Bacon.

Tacoma-Pierce County Health Department. (2005). Board of Health Resolution 2005-3698. Online: http://www.tpchd.org/files/library/b042eda3ce9c9999.pdf 
U.S. Department of Health and Human Services. (January 2010). The Surgeon General's Vision for a Healthy and Fit Nation. Rockville, MD: U.S. Department of Health and Human Services, Office of the Surgeon General.

(C) Copyright of Journal of Youth Development Bridging Research and Practice. Content may not be copied or emailed to multiple sites or posted to a listserv without copyright holder's express written permission. Contact Editor at: patricia.dawson@oregonstate.edu for details. However, users may print, download or email articles for individual use.

ISSN 2325-4009 (Print); ISSN 2325-4017 (Online) 